\title{
Universiteit
}

Leiden

The Netherlands

\section{Peaks and pitfalls of multilevel policy coordination: analyzing the South American Conference on Migration}

Finn, V.J.; Doña-Reveco, C.

\section{Citation}

Finn, V. J., \& Doña-Reveco, C. (2021). Peaks and pitfalls of multilevel policy coordination: analyzing the South American Conference on Migration. Migration Letters, 18(4), 487-496. doi:10.33182/ml.v18i4.1234

Version: $\quad$ Accepted Manuscript

License: $\quad$ Leiden University Non-exclusive license

Downloaded from: https://hdl.handle.net/1887/3214366

Note: To cite this publication please use the final published version (if applicable). 


\title{
Peaks and Pitfalls of Multilevel Policy Coordination: Analyzing the South American Conference on Migration
}

\author{
Victoria Finn ${ }^{1}$ \\ Cristián Doña-Reveco ${ }^{2}$
}

\begin{abstract}
Please cite this pre-print as: Finn, V., \& Doña-Reveco, C. (2021). Peaks and Pitfalls of Multilevel Policy Coordination: Analyzing the South American Conference on Migration. Migration Letters 18(4): 487-496, doi.org/10.33182/ml.v18i4.1234.
\end{abstract}

\begin{abstract}
Regional Consultative Processes (RCPs) have become a central component of migration governance; these are the loci of interstate migration policy discussions. Currently 15 RCPs meet worldwide in every region, except the Caribbean, to form non-binding agreements and to coordinate migration policy approaches. Building on previous reports, migration governance literature, and existent thematic analyses specific to the region, we evaluate RCPs' multilevel migration policy coordination by comparing national laws to regional topics and accords. We compare two decades of national legislation in all 12 South American countries to regional discussion at the South American Conference on Migration (SACM) since its first annual meeting in 2000. We find synergies and discrepancies between translating regional migration governance strategies from the RCP into national-level migration management. The SACM has reinforced the member states' focus on regional integration and provided a space for dialog to agree on approaches and best practices. Yet, countries have not uniformly incorporated these into national legislation. Our multilevel analysis reveals the complexities that RCPs face in overcoming regional-national discrepancies in immigration policy coordination.
\end{abstract}

Keywords migration governance, migration management, multilevel policy, regional consultative processes, South America

\footnotetext{
${ }^{1}$ Leiden University \& Universidad Diego Portales; email: VickiJFinn@gmail.com

${ }^{2}$ University of Nebraska-Omaha; email: CDona@unomaha.edu
} 


\section{Introduction: Migration Governance and Multilevel Policy}

Migration governance is a two-step organizational process of understanding how economic, political, social, demographic, and environmental conditions impact immigrant receiving societies, then how policymakers attempt to manage these effects (Mármora, 2010; Geddes et al., 2019). Opposed to other studies analyzing a multilevel approach to migration governance as the regional and international levels (e.g., Lavenex, 2019), we evaluate the two levels as 1) regional-level discussion and agreements among member states at the RCP and 2) national-level migration policy within individual RCP member states.

RCPs are involved in migration governance since member states meet periodically to discuss migration topics and establish interstate approaches to migration in a setting coordinated by a 'neutral' organization such as the International Organization for Migration (IOM). By discussing shared challenges, government representatives frame the conditions and characteristics around migration. They then agree on best practices and make plans to reach the goal of policy coordination via projected changes in national-level immigration policies, through making sense of the current scenario. Sensemaking is "the process by which the frames produced, which provide a common understanding of the challenges faced by actors, are translated into action" and connects what is "going on" with "what to do next" (Lixi, 2019: 92). As Geddes and colleagues (2019) point out, such regional-level governance systems are not passive or reactive to migration changes but rather can shape their environment.

RCPs shape the migration environment through their unique positioning between the regional level and the global arena (forums, agendas, pacts, organizations, etc.). Member states participate in the regional annual meetings and form non-binding agreements to coordinate migration policy approaches and agree on migration management strategies (Klekowski von Koppenfels, 2001; Klein Solomon, 2005). The IOM (2020a) reports that it offers expertise, policy guidance, and capacity building to member states at and between meetings. In South America, Hansen (2010) has found that RCP efforts have resulted in changed national-level migration policies.

Since RCPs facilitate interstate migration policy discussions, they are positioned to connect regional aims to domestic policy. Despite being non-binding, one of the three main RCP goals is "Policy Impact" meaning that RCP member states can review, create, or amend migration-related legislation and "in several cases, participation in RCPs has also led to regional coherence in migration policy" (IOM, 2020b). In short, decisionmakers attend the annual meetings and use its non-binding agreements to draft migration policy 'back home' incorporating all, some, or none of the aspects from RCP discussions. As Table 1 shows, we observe a two-step, two-level migration governance process. 
Table 1 Migration Governance: Two Steps at Two Levels

\begin{tabular}{|c|c|c|c|c|}
\hline & & & Regional Level & National Level \\
\hline & (๑) & Main actors & $\begin{array}{c}\text { All RCP member states, } \\
\text { plus international organi- } \\
\text { zations }\end{array}$ & $\begin{array}{l}\text { Each member state, plus } \\
\text { influential domestic actors }\end{array}$ \\
\hline & $\theta$ & Main goal & $\begin{array}{l}\text { Harmonize migration } \\
\text { policy across the region }\end{array}$ & $\begin{array}{l}\text { Draft and implement } \\
\text { in-country migration policy }\end{array}$ \\
\hline $\begin{array}{l}\text { Migration } \\
\text { Governance }\end{array}$ & $\rightarrow$ & $\begin{array}{c}\text { Step } 1 \\
\text { Sensemaking }\end{array}$ & $\begin{array}{l}\text { Consider global and regional } \\
\text { migration themes then } \\
\text { establish regional interstate } \\
\text { approaches to migration }\end{array}$ & $\begin{array}{c}\text { Consider domestic politics, } \\
\text { existent national legislation, } \\
\text { international accords, } \\
\text { global agenda, and regional } \\
\text { approaches }\end{array}$ \\
\hline & 8 & $\begin{array}{c}\text { Step } 2 \\
\text { Migration } \\
\text { management }\end{array}$ & $\begin{array}{c}\text { Member states agree on } \\
\text { best practices and sign } \\
\text { non-binding action plans } \\
\text { and accords }\end{array}$ & $\begin{array}{l}\text { Member states maintain } \\
\text { or change domestic policy }\end{array}$ \\
\hline
\end{tabular}

Source: Applying insights on regional migration governance from Geddes et al. (2019).

Analyzing these two steps produces policy-relevant research because sensemaking and migration management occur at the regional level, then repeat at the national level. States consider RCP accords, but these are non-binding. A lack of enforcement, monitoring, and sanctioning mean that member states can decide which parts - if any_of the regional agreements about migration approaches and best practices to adopt or incorporate into its migration policies. As we argue, the lack of coordination stems from moving from the regional to the national level because overall migration governance decisions seem to heavily depend on domestic politics.

\section{Migrant Rights and Governance in South America}

South America has historically promoted different forms of integration processes between countries, that with time have come to include migration governance. Examples of these are the CAN (the Andean Community), the now defunct Unasur (the Union of South American Nations), and Mercosur (the Southern Common Market). CAN, founded in 1969, incorporated decisions regarding intraregional migration in 1996 with the Andean Migration Card (Decision 397) and with the Andean Instrument of Labor Migration in 2003 (Decision 545). Unasur proposed South American citizenship to facilitate free continental movement (Ramírez, 2016). Mercosur initially (1991-2001) aimed for a common market like European economic integration, then took a "social turn" and began focusing 
on migrants' rights in the 2002-2016 period (Brumat and Acosta, 2019: 57-59). As Acosta and Freier (2018) suggest, including social rights in Mercosur was due to a normative shift that organically emerged within the region, rather than from global factors.

Such cooperation is also found at the South American Conference on Migration (SACM), the Regional Consultative Process established in 2000. All 12 South American countries are members: Argentina, Bolivia, Brazil, Chile, Colombia, Ecuador, Guyana, Paraguay, Peru, Suriname, Uruguay, and Venezuela. The SACM is a space to discuss and create a regional agenda with the intention of member states taking these discussions to implement best practices domestically (Hansen, 2010; Harns, 2013; Mármora, 2016). Except in 2005 and 2019, the annual conference has so far met yearly, rotating its meeting location among the 12 member countries. Due to the Covid-19 pandemic, SACM met virtually in 2020; the presidency has changed from Peru to Argentina and has scheduled to meet again in 2021. Guyana and Suriname started participating intermittently from 2006, then have attended regularly since 2010. Member states' cabinet-level representatives attend, as do observers such as representatives from other governments, civil society, and international organizations.

The SACM has greatly supported regional initiatives, taking an official position to promote migration policies supporting development and regional integration (CSM-OSUMI, 2020), while such integration has seen advances and setbacks. Migrant rights and openness have returned to more restrictive migration governance since 2017 in South America, with political discourse focusing on managing and controlling migration (Brumat, Acosta, and Vera-Espinoza, 2018: 205). Unasur disbanded in March 2019 after most member states withdrew support—dissolving the proposed South American citizenship. In this context of increasing restrictions, the Mercosur Residence Agreement still facilitates intraregional migration (for the English translation, see Acosta and Finn, 2019). As Mercosur member countries, Argentina, Brazil, Paraguay, and Uruguay signed the Agreement, along with Bolivia and Chile as associated countries; later Colombia, Ecuador, and Peru also adopted it

The Mercosur Residence Agreement was drafted in 2002 then entered into force in 2009. Between 2009 and 2016, approximately 2.7 million migrants obtained (temporary or permanent) visas through the Agreement - although Argentina alone accounts for over 2 million of these issued visas (IOM, 2018: 58). The Agreement's aim was to eliminate undocumented intraregional migration, but regional migrants can still have an irregular legal status. As its name implies, the Agreement offers the right to reside but as Brumat and Acosta (2019) highlight, it excludes the right of entry; so while its successes have been a step in the right direction, it has thus far failed to create a South American free mobility regime. As Ramírez and colleagues (2017: 24-27) point out, visas stemming from Mercosur have 
helped regional migrants gain rights and better access to formal labor markets, but it still needs to be accompanied by a free movement agreement.

Beyond supporting the right to reside through the Mercosur Residence Agreement, human rights have formed a pillar in SACM discussion since its start, alongside migration policy coordination, or a need for the "harmonization of migration policies in the region" (Harns, 2013; Mármora, 2016: 37; Finn, Doña-Reveco, and Feddersen, 2019; see Table 2). Despite Mármora's (2010) description of the South American model of migratory governability as a human development approach to migration that puts migrant rights at the center of migration policy, legislation varies throughout the region. Moreover, migrant rights-centered policies unevenly focus on emigrants. South American states attempt to engage with and protect nationals abroad, for example by allowing dual nationality, offering tax breaks, and guaranteeing access to judicial processes overseas (Pedroza, Palop-García, and Hoffmann, 2016; Acosta, 2018). Mármora (2016) reports that concerns over emigrants abroadespecially in the European Union and United States-had been a major reason for establishing the conference.

\section{Table 2 SACM Meeting and Policy Priorities}

\begin{tabular}{|l|l|}
\hline 1. & Ensure migrant human rights, regardless of status \\
\hline 2. & Promote migration discourse related to development \\
\hline 3. & Strengthen dialogue and political coordination among member states \\
\hline 4. & Highlight migrants' contributions to welfare and cultural enrichment \\
\hline 5. & Promote participation from civil society \\
\hline
\end{tabular}

Source: IOM (2020b).

While most migration flows in South America are intraregional (Cerrutti and Parrado, 2015; UN DESA, 2017), some changes in immigration policy have also stemmed from concern over emigrants. A country opts to make immigration policy more inclusive, hoping other countries will follow suit, bringing more equal treatment for the first country's emigrants abroad (Acosta and Freier, 2018). An issue in overcoming this imbalance is a reluctance to recognize the immigrant-emigrant duality, reflected in impersonal terms in SACM documents, such as the "treatment of persons," "the migrant person as a subject to the law," and "nationals" (CSM-OSUMI, 2020). This language has been used 
despite both the regional 'social turn' and SACM's strong human rights focus (Acosta and Freier, 2018). Such phrasing curiously stresses a traditional migrant-country relation of subject-protection based on a state's legal jurisdiction rather than on intrinsic human rights.

In sum, at least in rhetoric, the SACM at the regional level has framed migration governance from a perspective of human rights for all migrants. However, important contradictions simultaneously exist since emigrants seemed to be positioned as more 'right worthy' than immigrants. Paraphrasing Pedroza (2020), given every emigrant is an immigrant, it would be unbalanced to take a rights-based perspective for emigration policies but not for immigration policy and immigrant rights throughout the region. Moving from the regional to national level, how does SACM's two main aims of human rights and policy coordination translate into legislation in the 12 countries?

\section{South American Migration Policy Coordination}

Coordinating policy from regional aims to national legislation has shown peaks and pitfalls. Even though RCP accords are non-binding, countries show an intention of action of implementing regional aims domestically. In 2002, they approved the Quito Action Plan, outlining how to reach regional objectives in national policy, including guidelines on how to protect migrant rights (Mármora, 2016: 38), which they discuss every year. Table 3 shows that of the 12 members, 11 have so far changed national-level legislation since the RCP began in 2000.

Table 3 Changed Migration Laws in South America, 2000-2021

\begin{tabular}{|l|l|l|}
\hline Argentina: 2003/2010 & Colombia: 2011 & Peru: 2017 \\
\hline Bolivia: 2013 & Ecuador: 2017 & Suriname: N/A \\
\hline Brazil: 2017 & Guyana: 2012 & Uruguay: 2008 \\
\hline Chile: 2021* & Paraguay: 2015 & Venezuela: 2004 \\
\hline
\end{tabular}

Sources: Laws from Bolivia, Brazil, Guyana, and Venezuela come from ILO (2018) using the "migrant worker" subject to search for policies; the rest are from OAS (2018) using the "national or federal laws" (leyes nacionales o federales) category. *In April 2021, Chile promulgated, but has not yet regulated, a new migration law (see Chile's Library of Congress, http://bcn.cl/2oodq). 
Three countries are special cases. First, Suriname has never had migration legislation, so change is not applicable. Second, Guyana-which uses common law-has modified migration legislation but in ways unrelated to the SACM. For such reasons, Suriname and Guyana are often excluded from migration studies in South America; however, we include them since they are active SACM member states. Third, Chile's 1975 Migration Law (DL 1094) was enshrined during dictatorship, took a security focus, and did not mention migrant rights (see Finn, Doña-Reveco, and Feddersen, 2019; Thayer, 2019). In 2010, Chile enacted a new law specifically for refugees (Law 24530), removing this category of 'migrants' from DL 1094. In April 2021, after almost a decade of debate, Chile promulgated a new migration law, although the proposed legislation took a step away from human rights (Vásquez et al., 2021). The incumbent government has also implemented other restrictive migration management measures, for example using executive decree power in 2018 that, as Finn and Umpierrez de Reguero (2020) explain, are inclusive in language but aim at exclusionary migration policy outcomes.

The remaining nine countries have changed migration legislation since 2000 and have indeed adopted a human rights approach to migration (especially, on paper, to asylum seekers)—nonetheless, countries differ in what they mean by migrant rights. Three countries have taken the most expansive approach, or best practice, recognizing the right to migrate as a human right: Argentina (Law 25871 of 2003/2010), Bolivia (Law 370 of 2013), and Ecuador (2017 Organic Law of Human Mobility) (OAS, 2018). Brazil is now more expansive as compared to its own migration policy history, but more restrictive than the SACM's discussions, aims, and agreements. Brazilian Law 13445 of 2017 included language giving immigrants the same rights as nationals-but President Temer (2016-2018) vetoed significant components that included some of those rights. Colombian Law 1465 of 2011 sidesteps immigration to focus on assisting emigrants abroad who want to return. While highlighting the integral respect for human rights of migrants and their families (reflecting the United Nation's international convention on the topic), it fails to expand on its application.

Despite the SACM's support of the Global Compact for Safe, Orderly and Regular Migration, in 2018 Chile decided not to sign the agreement, while Brazil's President Bolsonaro withdrew from the Compact shortly after his inauguration in January 2019. These are important signals showing that expansiveness toward SACM priorities is fickle and dependent on domestic politics-evident with two types of changes, in administrations and in migration flows.

First, moving from a left- to right-leaning government, Argentina made a restrictive attempt in 2017 (Decree 70/2017) to purposely clash its 2004 law protecting migrants' rights (Cerrutti and Parrado, 2015). The attempt was overturned, showing a step away from restrictive policy. Government 
ideology is not determinative of output: Evo Morales' leftwing government in Bolivia made Venezuelan immigrants 'invisible' by not processing their refugee applications (OAS, 2020), even though the same government had enshrined rights-based migration policy in 2013 (Finn, DoñaReveco, and Feddersen, 2019; Freier and Parent, 2019).

Second, major changes in migration flows from Venezuela since 2015 are testing the resilience of more pro-migrant rights national legislation (see Brumat, 2021). As of early 2020, Acosta and Brumat (2020) report that of 5.2 million Venezuelan nationals who live abroad reside throughout the region, most numerous in Colombia, then followed by Peru, Chile, Ecuador, Brazil, and Argentina. As the main destination of Venezuelan immigrants, these flows are testing Colombia's 2011 law-which it is failing. Chile, Colombia, and Peru implemented ad-hoc special permits, but migrants face various problems in acquiring them (due to a lack of information, cost, location of requesting visa, obtaining necessary documents, etc.) (Freier and Parent, 2019; Finn and Umpierrez de Reguero, 2020; Freier and Castillo Jara, 2020). Since such visas were not previously required, they create barriers to intraregional mobility, thus missing a chance to solidify regional integration and ensure human rights. For Venezuelans, Bolivia made a new regularization process and Paraguay has made no new policy or visa in response (Freier and Castillo Jara, 2020).

Regarding policy coordination at the regional level, according to the final declarations from the 2017 and 2018 meetings, the SACM has not created resolutions on the origins, characteristics, or effects of Venezuelan migration, meaning an inexistent unified SACM response. However, Venezuelan migration has been discussed in a different forum, the Quito Process. Most SACM members participate in it (along with Costa Rica, Mexico, and Panama), except Bolivia, Guyana, Suriname, and Venezuela. The Quito Process shares some RCP characteristics, such as using nonbinding agreements. The process has nonetheless led to some policy coordination, such as easing entry requirements for Venezuelan migrants by accepting expired travel documents (Freier and Parent, 2019). Except for Mexico and Uruguay, the remaining Quito Process members agreed at some point to accept expired Venezuelan passports to enter the countries, although that is no longer the case. Given the continued Venezuelan emigration, several of the countries decided to request specific visas that in practice restrict entrance, hence contravening the spirit of the agreement. Again, when it comes to migration policy, the lack of binding agreements allows South American countries to prioritize internal politics over regional agreements (Freier and Castillo Jara, 2020; Brumat, 2021).

Initially aligned with SACM and regional accords, and as a best practice, some countries had extended residence permits based on Mercosur (Argentina, Brazil, and Uruguay) and Unasur 
(Ecuador). Yet some of these reactions were afterwards replaced by using a more security-based approach and criminalizing select immigrants, while favoring others (in Brazil, Colombia, Ecuador, and Peru) (Freier and Castillo Jara, 2020). Brazil took an inclusive step in late 2019, establishing a fasttrack legal route for Venezuelans to gain refugee status, based on prima facie recognition (Acosta and Madrid, 2020); yet Brazil and Chile are not part of the Global Compact for Safe, Orderly and Regular Migration - an agreement that the SACM supports — thus showing a mixed bag of migration-related political stances and policy.

\section{Conclusion}

Multilevel policy coordination, a goal of the South American Regional Consultative Process, has shown peaks and pitfalls over the last two decades, 2000-2020. Peaks include member states' yearly commitment to open dialogue on migration and development topics, promotion of regional integration, and agreement on migration-related best practices. Since protecting migrant human rights is a SACM priority, fitting well with promoting international agreements, the right to migrate as a human right would be best practice, which Argentina, Bolivia, and Ecuador have enshrined into law. Using existent agreements to face changes, such as outflows from Venezuela, would also be a best practice (as Argentina, Brazil, Ecuador, and Uruguay have done), whereas other members reacted with no change (Paraguay) or ad-hoc policy (Bolivia, Chile, Colombia, and Peru).

Despite these regional advances, pitfalls occur while translating regional dialogue into domestic migration management, as structured in Table 1. As a result, the SACM has not fully coordinated migration policy. At the regional level, RCP member states together undertake the two steps of migration governance: sensemaking and migration management (Geddes et al. 2019; Table 1). Then at the national level, member state decisionmakers repeat these two steps, resulting in maintaining or changing domestic policy. As Lavenex (2019: 1282) points out, the regional SACM takes a human rights approach while "leaving control aspects to national regulations"- -hinting at why the regional level may not necessarily transfer smoothly to the national level.

Given the discrepancies arising between the two levels, policy coordination could improve with a) binding agreements, b) supranational structures, or c) institutionalized migration governance strategies at the regional level. Such changes would allow members to make rules to monitor and enforce compliance, creating accountability mechanisms (Ostrom, 1990). As it stands now, when member states align national policy with the RCP's positions, immigration policies are fickle over time. For example, newly elected governments with different stances may attempt to reverse rights, such as 
in Argentina in 2017 (Cerrutti and Parrado, 2015), or implement more restrictive migration management measures through executive decrees, such as in Chile in 2018 (Finn and Umpierrez de Reguero, 2020).

The South American region has come far since the 1990s and even further since SACM was established in 2000. But the SACM still has a long road ahead to fully reach the policy aims of ensuring migrant human rights, regardless of legal status, and strengthening political coordination among member states (see Table 2). Convergence between regional agreements and a migrant human rights frame versus national-level legislation and policies would bring more consistency over time and united responses during crisis. Moreover, South American countries have not turned to the SACM as a force to facilitate a unified regional response to crises, neither the Venezuelan displacement nor the Covid19 pandemic. Instead, countries have reacted mostly with unilateral restrictive responses to migration flows, such as by increasing securitization-based policies (Acosta and Brumat, 2020). The results of this multilevel analysis may serve other RCPs since we find an opportunity to harmonize policies during the migration governance steps of sensemaking and migration management. RCPs must strategize how to merge these two steps between the regional and national levels to converge migration governance strategies and to apply them evenly toward all migrants throughout the region. 


\section{References}

Acosta, D. (2018). The National versus the Foreigner in South America: 200 Years of Migration and Citizenship Law. Cambridge: Cambridge University Press.

Acosta, D. and Brumat, L. (2020). "Political and legal responses to human mobility in South America in the context of the Covid-19 crisis. More fuel for the fire?" Frontiers in Human Dynamics. https://doi.org/10.3389/fhumd.2020.592196

Acosta, D. and Finn, V. (2019). Unofficial English Translation of the MERCOSUR Residence Agreement. Accessed 21 May 2020: http://www.diegoacosta.eu/portfolio-items/unofficialenglish-translation-of-the-mercosur-residence-agreement/?portfolioCats $=55$

Acosta, D. and Freier, L. F. (2018). "Regional Governance of Migration in South America". In: A. Triandafyllidou (ed.) Handbook of Migration and Globalisation, Cheltenham, UK: Edward Elgar Publishing. https://doi.org/10.4337/9781785367519.00011

Acosta, D. and Madrid, L. (2020). “¿Migrantes o refugiados? La Declaración de Cartagena y los venezolanos en Brasil” [Migrants or Refugees? The Cartagena Declaration and Venezuelans in Brazil]. Fundación Carolina, Documentos de Trabajo 9/2020, Madrid. https://doi.org/10.33960/AC 09.2020

Brumat, L. (2021). "Gobernanza migratoria en Suramérica en 2021: respuestas a la emigración venezolana durante la pandemia" [Migration Governance in South America in 2021: Responses to Venezuelan emigration during the pandemic]. Análisis Carolina 12. https://doi.org/10.33960/AC 12.2021

Brumat, L. and Acosta, D. (2019). "Three Generations of Free Movement of Regional Migrants in Mercosur: Any influence from the EU?” In: A. Geddes, M. V. Espinoza, L. Hadj-Abdou and L. Brumat (eds.) The Dynamics of Regional Migration Governance, Cheltenham, UK: Edward Elgar Publishing. https://doi.org/10.4337/9781788119948.00009

Brumat, L., Acosta, D. and Vera-Espinoza, M. (2018). "Gobernanza migratoria en América del Sur: ¿hacia una nueva oleada restrictiva?” [Migration Governance in South America: Towards a new restrictive wave?]. In: L. Bizzozero Revelez and W. Fernández Luzuriaga (eds.) Anuario política internacional \& politica exterior 2017-2018, Montevideo, Uruguay: FCS, Cruz del Sur.

Cerrutti, M. and Parrado, E. (2015). "Intraregional Migration in South America: Trends and a Research Agenda". Annual Review of Sociology, 41: 399-421. https://doi.org/10.1146/annurev-soc-073014$\underline{112249}$

CSM-OSUMI. (2020). Conferencia Suramericana sobre Migraciones - Observatorio Suramericano sobre Migraciones [South American Conference on Migration- South American Observatory on Migration]. Accessed 5 November 2020: www.csm-osumi.org

Finn, V., Doña-Reveco, C. and Feddersen, M. (2019). "Migration Governance in South America: Regional Approaches versus National Laws”. In: A. Geddes, M. V. Espinoza, L. Hadj-Abdou and L. Brumat (eds.) The Dynamics of Regional Migration Governance, Cheltenham, UK: Edward Elgar Publishing. https://doi.org/10.4337/9781788119948.00008 
Finn, V. and Umpierrez de Reguero, S. (2020). "Inclusive Language for Exclusive Policies: Restrictive Migration Governance in Chile, 2018”. Latin American Policy, 11(1): 42-61. https://doi.org/10.1111/lamp.12176

Freier, L. F. and Castillo Jara, S. (2020). “El Presidencialismo y la 'Securitización' de la Política Migratoria en América Latina: Un Análisis de las Reacciones Políticas frente al Desplazamiento de Ciudadanos Venezolanos" [Presidentialism and Migration Politics in Latin America: Understanding policy reactions to the displacement of Venezuelan citizens]. Internacia: Revista de Relaciones Internacionales, 1 1: 1 -28. http://revistas.pucp.edu.pe/index.php/internacia/article/view/21840

Freier, L. F. and Parent, N. (2019). "The Regional Response to the Venezuelan Exodus". Current History, 118(805): 56-61. https://doi.org/10.1525/curh.2019.118.805.56

Geddes, A., Vera Espinoza, M., Hadj Abdou, L. and Brumat, L. (2019). "Introduction: The dynamics of regional migration governance.” In: A. Geddes, M. V. Espinoza, L. Hadj-Abdou and L. Brumat (eds.) The Dynamics of Regional Migration Governance, Cheltenham, UK: Edward Elgar Publishing. https://doi.org/10.4337/9781788119948.00006

Hansen, R. (2010). An Assessment of Principal Regional Consultative Processes on Migration in IOM Migration Research Series, No. 38, International Organization for Migration, Geneva. https://publications.iom.int/system/files/pdf/mrs 38.pdf

Harns, C. (2013). Regional Inter-State Consultation Mechanisms on Migration: Approaches, Recent Activities and Implications for Global Governance of Migration in IOM Migration Research Series, No. 45, International Organization for Migration, Geneva. https://publications.iom.int/es/system/files/pdf/mrs45 en 10may2013.pdf

ILO: International Labour Organization. (2018). Database of National Labour, NATLEX. Social Security and Related Human Rights Legislation. Accessed 29 May 2020: https://www.ilo.org/dyn/natlex/natlex4.home?p lang=en

IOM: International Organization for Migration. (2018). Evaluación del Acuerdo de Residencia del MERCOSUR y su incidencia en el acceso a derechos de los migrantes [Evaluation of the MERCOSUR Residence Agreement and its implications for migrants accessing rights]. Cuadernos migratorios N.9. Accessed 5 November 2020:

https://publications.iom.int/system/files/pdf/estudio sobre la evaluacion_y el impacto del_acu erdo de residencia del mercosur.pdf

IOM (2020a). Regional Consultative Processes on Migration. Accessed 5 November 2020: https://www.iom.int/regional-consultative-processes-

migration\#: : text $=$ Regional $\% 20$ consultative $\% 20$ processes $\% 20$ on $\% 20$ migration $\% 20($ RCPs $) \% 2$ Oare $\% 20$ state $\% 2$ Dled,be $\% 20$ officially $\% 20$ associated $\% 20$ with $\% 20$ formal

IOM (2020b). South American Conference on Migration (SACM). Accessed 5 November 2020: https://www.iom.int/south-american-conference-migration-sacm

Klein Solomon, M. (2005). International Migration Management through Inter-State Consultation Mechanisms. Geneva: International Organization for Migration. 
https://www.un.org/en/development/desa/population/events/pdf/expert/8/P13 MKSolom on.pdf

Klekowski von Koppenfels, A. (2001). The Role of Regional Consultative Processes in Managing International Migration. IOM Migration Research Series, No. 3. Geneva: International Organization for Migration. https://publications.iom.int/system/files/pdf/mrs 3.pdf

Lavenex, S. (2019). "Regional Migration Governance - Building block of global initiatives?" Journal of Ethnic and Migration Studies, 45(8): 1275-1293.

https://doi.org/10.1080/1369183X.2018.1441606

Lixi, L. (2019). "The Ambivalent Drivers of Migration Governance Relations Between the EU and Tunisia." In: A. Geddes, M. V. Espinoza, L. Hadj-Abdou and L. Brumat (eds.) The Dynamics of Regional Migration Governance, Cheltenham, UK: Edward Elgar Publishing. https://doi.org/10.4337/9781788119948.00011

Mármora, L. (2010). "Modelos de Gobernabilidad Migratoria: La perspectiva política en América del Sur" [Migration Governability Models: The political perspective in South America]. REMHU Revista Interdisciplinar da Mobilidade Humana, 35: 71-92. http://remhu.csem.org.br/index.php/remhu/article/view/229/212

Mármora, L. (2016). Conferencia Suramericana sobre Migraciones 2000-2015. [South American Conference on Migration 2000-2015]. International Organization for Migration, Buenos Aires, Argentina.

https://robuenosaires.iom.int/sites/default/files/publicaciones/Conferencia $\% 20$ Suramericana $\% 20 \mathrm{~s}$ obre $\% 20$ Migraciones $\% 202000 \% 20-\% 202015$.pdf

OAS: Organization of American States. (2018). Database of Migration Legislation in the Americas, MILEX. Accessed 29 May 2020: $\underline{\text { http://www.migracionoea.org/milex }}$

OAS (2020). Informe. Situación de los migrantes y refugiados venezolanos en Bolivia [Report: The status of Venezuelan migrants and refugees in Bolivia]. Oficina de la Secretaría General para la Crisis de Migrantes y Refugiados Venezolanos.

http://www.oas.org/documents/spa/press/Informe-situacion-migrantes-refugiados-venezolanosen-Bolivia.pdf.

Ostrom, E. (1990). Governing the Commons: The Evolution of Institutions for Collective Action. Cambridge University Press.

Pedroza, L. (2020). A Comprehensive Framework for Studying Migration Policies (and a Call to Observe Them beyond Immigration to the West). GIGA Working Paper, No. 321. https://www.giga-hamburg.de/en/system/files/publications/wp321 pedroza.pdf

Pedroza, L., Palop-García, P. and Hoffmann, B. (2016). Emigrant Policies in Latin America and the Caribbean. Santiago, Chile: FLASCO Chile.

http://www.flacsochile.org/publicaciones/emigrant-policies-in-latin-america-and-the-caribbean/ Ramírez, J. (2016). Hacia el Sur. La construcción de la ciudadanía Suramericana y la movilidad intrarregional [To the South: Constructing South American citizenship and intraregional mobility]. Quito, Ecuador: Centro Estratégico Latinoamericano de Geopolítica (CELAG). https://www.celag.org/wpcontent/uploads/2016/10/hacia-el-Sur Vfinal-16-03-2.pdf 
Ramírez, J., Iréri, C., Soledad, C., \& Romina, A. (2017). 'Ah, Usted viene por la visa Mercosur': Migración, integración y refugio en Ecuador ['Ah, You Have Come for the Mercosur Visa': Migration, integration, and refuge in Ecuador]. Quito, Ecuador: CELAG.

Thayer, L. E. (2019). "Causas y consecuencias de la migración irregular en Chile" [Causes and Consequences of Irregular Migration in Chile]. In: N. Rojas Pedemonte and J. T. Vicuña Undurraga (eds.) Migración en Chile: Evidencia y mitos de una nueva realidad [Migration in Chile: Evidence and myths of a new reality], Santiago, Chile: Servicio Jesuita a Migrantes.

UN DESA: United Nations, Department of Economic and Social Affairs, Population Division. (2017). Trends in International Migrant Stock: The 2017 Revision. United Nations database, POP/DB/MIG/Stock/Rev.2017.

https://www.un.org/en/development/desa/population/migration/data/estimates2/estimates1 7.asp

Vásquez, J., Finn, V., \& Umpierrez de Reguero, S. (2021). "Cambiando la cerradura. Intenciones legislativas del proyecto de Ley de Migraciones en Chile" [Changing the Padlock: Legislative intentions in Chile's migration law proposal]. Colombia Internacional 106: 57-87. https://doi.org/10.7440/colombiaint106.2021.03. 